\title{
Large indels obscure phylogeny in analysis of chloroplast DNA (trnL-F) sequence data: Pomaderreae (Rhamnaceae) revisited
}

\author{
Jürgen Kellermann ${ }^{1,2,3}$ and Frank Udovicic ${ }^{2}$
}

\author{
${ }^{1}$ School of Botany, The University of Melbourne, VIC 3010, Australia \\ ${ }^{2}$ National Herbarium of Victoria, Royal Botanic Gardens Melbourne, \\ Birdwood Avenue, South Yarra, VIC 3141, Australia \\ ${ }^{3}$ Current address: State Herbarium of South Australia, Plant Biodiversity Centre, \\ P.O. Box 2732, Kent Town, SA 5071, Australia \\ Author for correspondence: kellermann.juergen@saugov.sa.gov.au
}

\begin{abstract}
Phylogenetic analysis of 69 ingroup-taxa of Pomaderreae using trnL-F sequences confirm the monophyly of the tribe. The analysis was impeded by a paucity of informative characters and the presence of apparently homoplasious indel characters and base changes within the P8 region of the trnL intron: the strict consensus tree of the $\operatorname{trn} \mathrm{L}-\mathrm{F}$ analysis is less resolved and had fewer supported clades than in a previous ITS analysis (Kellermann et al. 2005). The backbone of the cladogram is not supported and relationships between genera/clades are somewhat uncertain. The genera Cryptandra, Stenanthemum and Polianthion are well supported. Pomaderris groups with Siegfriedia and Trymalium, but only individual clades within these genera receive support. Blackallia biloba is related to two atypical species of Stenanthemum and B. connata to Cryptandra, but this grouping depends on the exclusion of homoplasious indel characters. Species of Spyridium only group in one clade when these indels are excluded, otherwise they are located in a polytomy at the base of the cladogram. The results mostly agree with earlier findings using ITS sequence data. Two new genera containing atypical species of Stenanthemum are suggested. A synopsis of the Australian genera of Rhamnaceae is provided.
\end{abstract}

Paper from the Australian Systematic Botany Society Conference held in Cairns, November 2006 


\section{Introduction}

Australia has a very rich Rhamnaceae flora with about one quarter of the world's species (c. 250 out of 950) occurring in the country. The majority of species (over 90\%) belong to the tribe Pomaderreae, which is almost endemic to Australia. The remaining 10\% of species are mostly from genera that are also widespread in the Malesian or Pacific region, and some species occur in southern Australia. A synopsis of the Australian genera of Rhamnaceae is presented in Table 1.

Species of Pomaderreae are found mainly in the temperate to semi-arid southern regions of Australia, but some occur in the tropical north, and arid centre of the continent, and eight taxa are found in New Zealand. There are about 230 species, which are currently classified in eight genera (Table 1). The complex taxonomic history of the major genera in the tribe is reviewed in Kellermann et al. (2005) and Kellermann (2007).

The tribe has been the focus of recent and on-going research in the Australian Rhamnaceae. Walsh revised Pomaderris and published an infrageneric classification of the genus (e.g., Walsh 1988, 1990; Walsh \& Coates 1997). Rye (1995, 2001) re-instated the genus Stenanthemum and revised species from Western Australia (e.g., Rye 1996b).

Table 1. Currently accepted genera of Australian Rhamnaceae.

Tribal classification follows Medan \& Schirarend (2004) and Richardson et al. (2000b). Six genera of Rhamnaceae are not assigned to a tribe; five of these occur in Australia.

\begin{tabular}{|c|c|c|}
\hline Tribe & Genus & Species in Australia \\
\hline \multirow[t]{2}{*}{ Paluureae Reissek ex Endl. } & Hovenia Thunb. & 1 (introduced) \\
\hline & Ziziphus Mill. & 4 \\
\hline Colletieae Reissek ex Endl. & Discaria Hook. & 2 \\
\hline PhyLiceae Reissek ex Endl. & Noltea Rchb. & 1 (introduced) \\
\hline Gouanieae Reissek ex Endl. & Gouania Jacq. & 2 \\
\hline \multirow[t]{8}{*}{ Pomaderreae Reissek ex Endl. } & Blackallia C.A.Gardner & 2 \\
\hline & Cryptandra Sm. & c. 55 \\
\hline & Polianthion K.R.Thiele & 4 \\
\hline & Pomaderris Labill. & c. 70 \\
\hline & Siegfriedia C.A.Gardner & 1 \\
\hline & Spyridium Fenzl & $40-45$ \\
\hline & Stenanthemum Reissek & c. 30 \\
\hline & Trymalium Fenzl & 13 \\
\hline \multirow[t]{3}{*}{ RHAMnEAe Hook.f. } & Dallachya F.Muell. & 1 \\
\hline & Rhamnus L. & 2 (1 native, 1 introduced) \\
\hline & Sageretia Brongn. & 1 \\
\hline VeNTILAGINEAE Hook.f. & Ventilago Gaertn. & 3 \\
\hline \multirow[t]{5}{*}{ Genera incertae sedis } & Alphitonia Reissek ex Endl. & 5 \\
\hline & Colubrina Rich. ex Brongn. & 1 \\
\hline & Emmenosperma F.Muell. & 2 \\
\hline & Granitites Rye & 1 \\
\hline & Schistocarpaea F.Muell. & 1 \\
\hline
\end{tabular}


An atypical species of Pomaderris was excluded from the tribe and segregated into its own genus, Granitites (Rye 1996a). Thiele \& West (2004) and Thiele (2007) elucidated the delimitations of the genera Cryptandra, Spyridium and Stenanthemum. Bean (2004) published new species of Cryptandra and Stenanthemum for Queensland. Kellermann (2006b, 2007) clarified the position of several Spyridium taxa that were misplaced in other genera. The revision of the south-eastern species of Cryptandra has resulted so far in three publications (Kellermann 2006a, 2006c; Kellermann \& Udovicic 2007). Kellermann et al. (2005) published a molecular phylogeny using ITS sequence data, as a result of which a new genus, Polianthion K.R.Thiele, was established (Kellermann et al. 2006).

The ITS phylogeny confirmed the monophyly of Pomaderreae, corroborating earlier results by Richardson et al. (2000a) and Fay et al. (2001). The clades found in the strict consensus tree were mostly consistent with the currently accepted genera in the tribe. Some species were clearly misplaced, but re-examination of the morphology of these species confirmed their placement in the molecular phylogeny. The major genera/ clades, except Stenanthemum and Blackallia, received moderate to strong bootstrap and jackknife support. Stenanthemum was split into two well-supported clades with the atypical St. gracilipes inserted in between the two clades. Blackallia biloba and St. grandiflorum were sister taxa, and not allied to any of the remaining genera; B. connata was placed in Cryptandra.

This study was initiated to clarify questions that could not be resolved in the analysis of ITS data (Kellermann et al. 2005) and to augment the molecular data-set available for Pomaderreae with sequences from the trnL-F region of cpDNA. In this paper, the resulting phylogenies of the trnL-F analysis are presented and we report on the presence of unforeseen problems relating to the structure of the trnL-F region, which hampered and complicated the cladistic analysis of the data. The results add to the base of knowledge needed for the completion of the Flora of Australia treatment of Rhamnaceae (K.R. Thiele, F. Udovicic, N.G. Walsh \& J. Kellermann, in prep.).

\section{Materials \& Methods}

Sixty-nine ingroup taxa were sequenced from all genera of Pomaderreae. The outgroup consisted of five species from related tribes of Rhamnaceae. Voucher and collection details are listed in Appendix 1. Manuscript names of taxa are used as they are listed in FloraBase (http://florabase.calm.wa.gov.au) at the time of writing (Mar. 2007). In this paper, the abbreviations used for the genera Pomaderris, Polianthion, Siegfriedia, Spyridium and Stenanthemum are 'P.', 'Pol.', 'Si.', 'Sp.' and 'St.'.

\section{Choice of DNA region}

The trnL-F region consists of the complete trnL intron, $\operatorname{trn} \mathrm{L}$ 3' exon, and the intergenic spacer (IGS) between the $\operatorname{trn} \mathrm{L}$ and the $\operatorname{trn} \mathrm{F}$ genes of the chloroplast genome. These genes encode the chloroplast's transfer RNA for Leucine and Phenylalanine, respectively. Both the trnL intron and the trnL-F IGS are non-coding regions. The trnL intron is the only group I intron in the chloroplast genome and has a conserved secondary structure (Simon et al. 2004). 
The trnL-F region was first used in phylogenetic analyses of Gentiana L. (Gielly \& Taberlet 1994) and Crassulaceae (Ham et al. 1994). Currently, it is applied in studies at all taxonomic levels. Borsch et al. (2003) used the $t r n \mathrm{~T}-t r n \mathrm{~F}$ region, which includes the $t r n \mathrm{~L}-\mathrm{F}$ region, to infer a phylogeny of basal angiosperms. Most frequently, however, $\operatorname{trn} \mathrm{L}-\mathrm{F}$ is used for infrafamilial studies, e.g., in Araliaceae (Plunkett et al. 2004), Gentianaceae (Yuan et al. 2003), Oxylobium Andrews and related genera (Crisp \& Cook 2003), or Acacia Mill. (Murphy et al. 2000).

The region has already been employed to examine the relationships of Rhamnaceae with other families (Sytsma et al. 2002; Thulin et al. 1998), to resolve the tribal limits of the family (Fay et al. 2001; Richardson et al. 2000a, b), and in studies on the genera Ceanothus Mill. (Islam \& Simmons 2006), Phylica L. (Richardson et al. 2001) and Rhamnus L. s. lat. (Bolmgren \& Oxelman 2004).

\section{DNA isolation and sequencing}

Genomic DNA was isolated using the method described in Kellermann et al. (2005). A few samples of the trnL-F region had to be purified using the QIAquick Gel Extraction Kit (QIAGEN). The trn L-F region was amplified using the primers designed by Taberlet et al. (1991). For most species the whole region was amplified with primers $\mathrm{C}$ and $\mathrm{F}$ with one hold at $95^{\circ} \mathrm{C}$ for 15 min preceding 30 cycles of $94^{\circ} \mathrm{C}$ for $30 \mathrm{~s}, 58^{\circ} \mathrm{C}$ for $30 \mathrm{~s}$, $72^{\circ} \mathrm{C}$ for $30 \mathrm{~s}$, and followed by one hold at $72^{\circ} \mathrm{C}$ for $5 \mathrm{~min}$. In other species, the $\operatorname{trn} \mathrm{L}$ intron and the trnL-F IGS had to be amplified separately using primer pairs C/D and $\mathrm{E} / \mathrm{F}$, respectively. While the $\operatorname{trn} \mathrm{L}-\mathrm{F}$ IGS amplified readily, the annealing temperature frequently had to be lowered to $55^{\circ} \mathrm{C}$ or $52^{\circ} \mathrm{C}$ when amplifying the $\operatorname{trn} \mathrm{L}$ intron. Some species with a low yield of genomic DNA, in particular from herbarium specimens, had to be amplified with a semi-nested PCR protocol (Udovicic \& Murphy 2002) using products from a previous amplification with primers $\mathrm{C}$ and $\mathrm{F}$ as template for a second round of PCR. In this second round the trnL intron and the trnL-F IGS were amplified using the primer pairs $\mathrm{C} / \mathrm{D}$ and $\mathrm{E} / \mathrm{F}$, respectively, and a lower annealing temperature of $55^{\circ} \mathrm{C}$. Amplification with primers $\mathrm{C}$ and $\mathrm{F}$ in the second round of PCR was unsuccessful, a fact already noted by Richardson et al. (2001) for other species of Rhamnaceae.

\section{Phylogenetic analysis}

Sequences were aligned as outlined in Kellermann et al. (2005) and analysed using the computer program PAUP*, version $4.0 \mathrm{~b} 10$ (Swofford 2002). Individual base positions were coded as unordered multistates and gaps were treated as missing data. Insertion/ deletion (indel) characters were coded as single binary characters. Uninformative characters were excluded from the data matrix.

A two step search was employed, since the computer ran out of memory when using a more straightforward search strategy (e.g., Kellermann et al. 2005). In the first round, a heuristic search was performed with 1000 replicates using random stepwise addition of taxa and TBR branch swapping. Only five trees were held in each replicate. All shortest trees collected in the 1000 replicates were then used as starting trees for a second round of heuristic search. All trees were swapped to completion, or until a maximum number of 10,000 trees was produced, at which point the search was limited and the 10,000 trees saved were swapped. Strict consensus and majority-rule consensus trees were calculated for the 10,000 equally parsimonious trees. Trees were rooted using the outgroup taxa (Maddison et al. 1984). 
To test the support for nodes in the tree, both bootstrap (Felsenstein 1985) and jackknife (Farris et al. 1996) values were calculated in PAUP*. Bootstrap analysis was carried out with 1,000 replicates, TBR branch swapping and a limit of 1,000 trees per replicate. To calculate jackknife values, the 'Jac' emulation as implemented in PAUP ${ }^{\star}$ was performed with 100,000 replicates and 37\% deletion, using the fast heuristic search option.

\section{Results}

\section{Sequences}

Sequences were obtained for 69 species of Pomaderreae and five outgroup species from related tribes. Two accessions were obtained for each of six taxa to test infraspecific variation: Cryptandra amara, C. mutila, Siegfriedia darwinioides, Spyridium globulosum, Sp. parvifolium and Trymalium ledifolium. The sequence variation between two sequences of the same species was $\leq 1.6 \%$ in all cases and in some cases, sequences were identical. Because of the low sequence variation, only a single sequence of each species, the first listed in Appendix 1, was used in the analysis of the trnL-F sequence data.

\section{Large indels}

In the alignment of the trnL-F sequences, several large indels were identified. In particular, one deletion of approximately 125 base pairs (indel no. 9) seemed to have occurred in unrelated species, a result revealed in the first analysis (A). Subsequently two more analyses were undertaken to explore the effect of indel no. 9 on the resulting topology of the tree. The following analyses of the $\operatorname{tr} n \mathrm{~L}-\mathrm{F}$ data-set were carried out:

Analysis A included all species and characters;

Analysis B excluded two of the three sequences with indel no. 9, namely those of Pomaderris rotundifolia and Cryptandra triplex, but included all characters;

Analysis C included all species, but excluded the DNA region in which indel no. 9 occurred, and all potential characters therein (following Quandt et al. 2004; see below for discussion).

\section{Characteristics of sequences \& phylogeny}

The alignment of the trnL-F data set had 1145 base positions. Four regions in the alignment were ambiguous and unalignable and therefore excluded from the analysis. This reduced the data-set by 46 characters to 1099 base positions. Twenty-three indels were identified in the alignment and coded separately using the simple indel coding method of Simmons and Ochoterena (2000).

When all species and all characters were included in analysis $\mathrm{A}$, the alignment provided 90 parsimony-informative characters $(8.2 \%)$ and 21 out of 23 indel characters were potentially informative characters. In analysis $B$, the number of parsimony-informative characters in the alignment was reduced due to the exclusion of two species: 87 base characters $(7.9 \%)$ and 20 of 23 the indels were potentially informative. Analysis $\mathrm{C}$ excluded a stretch of 261 bases from the alignment and reduced the number of 
characters to 838 base positions; this also eliminated 8 indel characters from the data-set. Analysis C included 67 potentially informative base characters (8.0\%), and 13 parsimony-informative indels.

In all three parsimony analyses, the maximum number of 10,000 trees was reached when using the two step search strategy. The trees of analysis A had a CI=0.566 and $\mathrm{RI}=0.789$. The $\mathrm{CI}$ and RI for analysis $\mathrm{B}$ were 0.564 and 0.786 , respectively. The trees in analysis $\mathrm{C}$ had a $\mathrm{CI}=0.572$ and a $\mathrm{RI}=0.805$. The strict consensus tree of analysis $\mathrm{A}$ (Fig. 1) showed 30 nodes common to all most parsimonious trees ( 27 nodes common to the ingroup); 23 nodes had bootstrap support (BS) and 22 nodes had jackknife support (JS) $\geq 50 \%$. The strict consensus of analysis B (excluding the sequences containing indel no. 9; Fig. 2), had 28 nodes (25 nodes in the ingroup), of which 21 had bootstrap support and 20 nodes had jackknife support above 50\%. Analysis C had 24 nodes present in the strict consensus tree (22 nodes in the ingroup; Fig. 3), statistical support $\geq 50 \%$ in the bootstrap and jackknife analyses was obtained for 19 nodes.

\section{Cladogram topology}

The strict consensus trees for analyses A and B are shown in Figures 1 and 2. Tree topology is the same in both cladograms, except that in analysis A the species containing indel no. 9 are grouped in one clade within the genus Trymalium. This clade is indicated in bold in Figure 1. Bootstrap (BS) and jackknife (JS) values differ only slightly between the analyses. The strict consensus in analysis C (Fig. 3) has a similar topology to the previous two trees, but is less resolved. However, the genus Spyridium was resolved in one clade (at node 3) in analysis C, and Blackallia connata grouped with Cryptandra (node 24) and not with Stenanthemum gracilipes, St. grandiflorum ms and B. biloba (clade at node 22). Only the tree in Figure 2 (analysis B) is discussed in the following sections and Figure 1 and 3 are only referred to when there are differences between the analyses.

Monophyly of the tribe Pomaderreae is very strongly supported with $100 \%$ bootstrap and jackknife support. Sister to Pomaderreae is either Schistocarpaea johnsonii (not placed in any tribe by Richardson et al. 2000b), Adolphia californica (tribe Colletieae), or a weakly supported clade (BS: 57\%; JS: <50\%) containing Alphitonia aff. incana (unplaced genus), Ceanothus coeruleus (unplaced genus) and Phylica buxifolia (tribe Phyliceae).

The backbone of the cladogram lacks bootstrap or jackknife support above $50 \%$ and thus the relationships among the main clades (genera) are unresolved. Of the currently accepted genera, only Cryptandra and two clades of Stenanthemum have bootstrap/ jackknife support. The species of Spyridium do not group in a clade in the strict consensus tree in analyses A and B. However, they form a clade in $94 \%$ of trees in a majority rule consensus tree (majority rule tree not shown). In analysis $\mathrm{C}$ the species of Spyridium are united in a clade, albeit without bootstrap or jackknife support above $50 \%$.

Within Spyridium, three species from New South Wales (Sp. scortechinii, Sp. buxifolium and $S p$. burragorang) form a weakly supported clade at node 4 . The two Tasmanian species included, Sp. ulicinum and Sp. gunnii, are sister taxa (node 6; BS: 61\%, JS: $58 \%$ ). Spyridium mucronatum and Sp. cordatum are strongly supported as sister taxa (node 7), but their relationship with the third Western Australian species included, Sp. globulosum, is unresolved. Spyridium daltonii and S. xramosissimum from the 


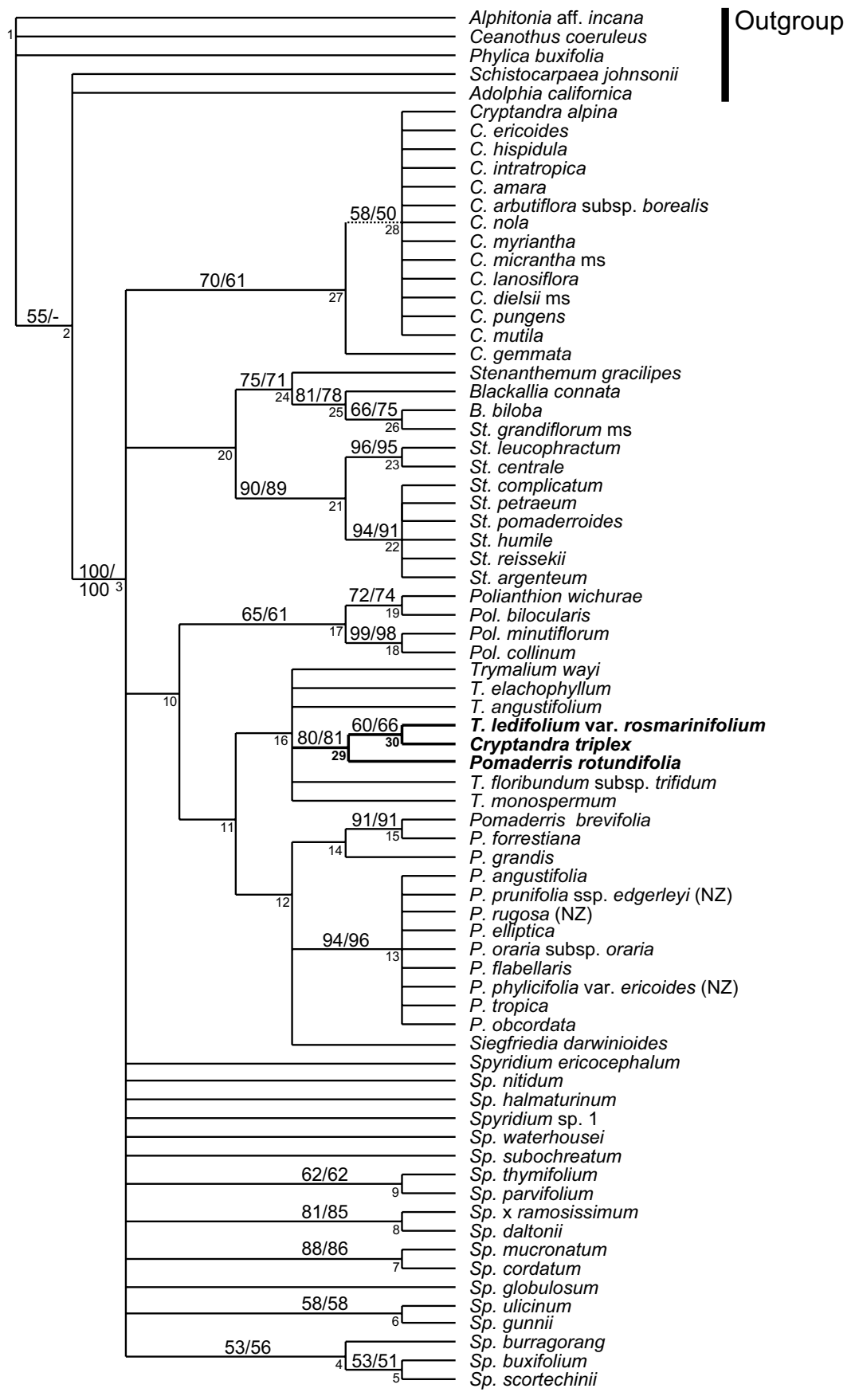

Fig. 1. Strict consensus tree of analysis A of the trnL-F data-set (10,000 equally parsimonious trees of 226 steps each, $\mathrm{CI}=0.57, \mathrm{RI}=0.79$ ), i.e., analysis of the full data-set. Bootstrap/jackknife values are indicated on branches. Node numbers are indicated in smaller type. The clade highlighted in bold contains taxa that share indel no. 9. The branch denoted by a dotted line is only present in bootstrap and jackknife analyses. Species from New Zealand are indicated (NZ). 


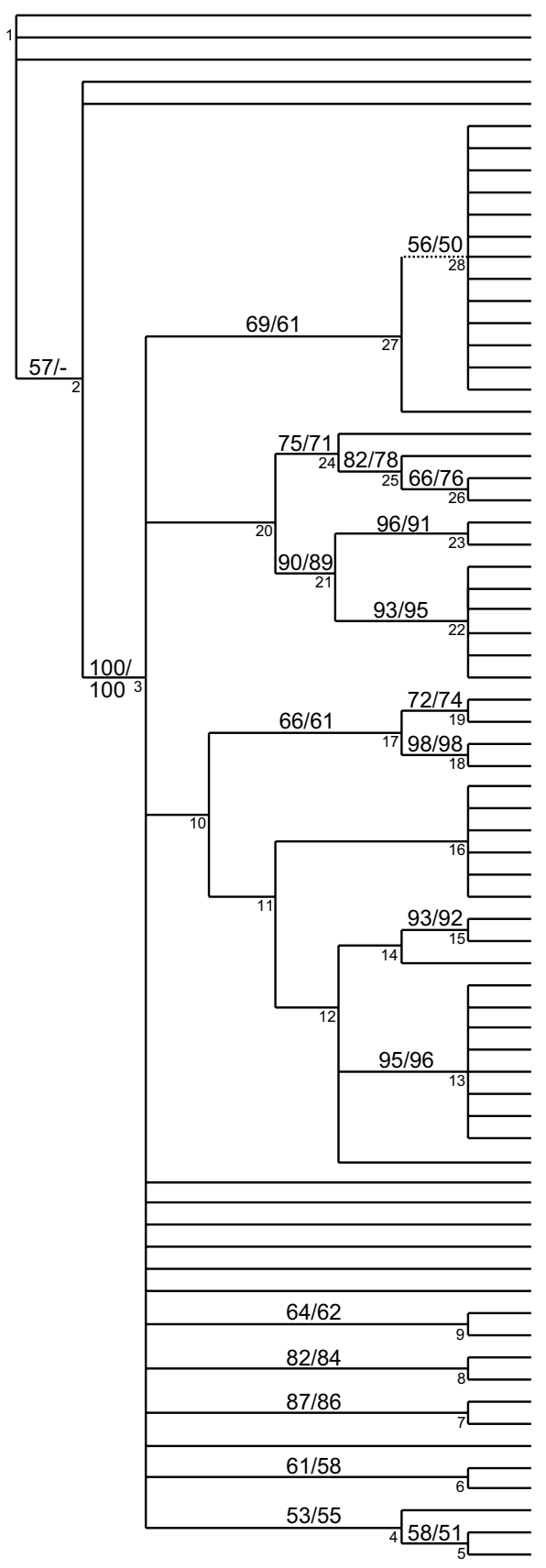

Alphitonia aff. incana

Ceanothus coeruleus

Phylica buxifolia

Schistocarpaea johnsonii

Adolphia californica

Cryptandra alpina

C. ericoides

C. hispidula

C. intratropica

C. amara

C. arbutiflora subsp. borealis

C. nola

C. myriantha

C. micrantha ms

C. lanosiflora

C. dielsii ms

C. pungens

C. mutila

Cryptandra gemmata

Stenanthemum gracilipes

Blackallia connata

St. grandiflorum ms

B. biloba

St. leucophractum

St. centrale

St. complicatum

St. petraeum

St. pomaderroides

St. humile

St. reissekii

St. argenteum

Polianthion wichurae

Pol. bilocularis

Pol. minutiflorum

Pol. collinum

Trymalium wayi

T. elachophyllum

T. angustifolium

T. ledifolium var. rosmarinifolium

T. florubundum subsp. trifidum

T. monospermum

Pomaderris brevifolia

P. forrestiana

$P$. grandis

$P$. angustifolia

P. prunifolia subsp. edgerleyi (NZ)

P. rugosa (NZ)

$P$. elliptica

$P$. oraria subsp. oraria

P. phylicifolia var. ericoides (NZ)

P. tropica

P. obcordata

Siegfriedia darwinioides

Spyridium ericocephalum

Sp. nitidum

Sp. halmaturinum

Spyridium sp. 1

Sp. waterhousei

Sp. subochreatum

Sp. thymifolium

Sp. parvifolium

Sp. x ramosissimum

Sp. daltonii

Sp. mucronatum

Sp. cordatum

Sp. globulosum

Sp. ulicinum

Sp. gunnii

Sp. burragorang

Sp. buxifolium

Sp. scortechinii

Fig. 2. Strict consensus tree of analysis $B$ of the $\operatorname{trn} \mathrm{L}-\mathrm{F}$ data-set (10,000 equally parsimonious trees of 220 steps each, $\mathrm{CI}=0.56, \mathrm{RI}=0.79)$, i.e., parsimony analysis excluding sequences from two taxa with indel no. 9 (Pomaderris rotundifolia, Cryptandra triplex). Bootstrap/jackknife values are indicated on branches. Node numbers are indicated in smaller type. The branch denoted by a dotted line is only present in bootstrap and jackknife analyses. Species from New Zealand are indicated (NZ). 


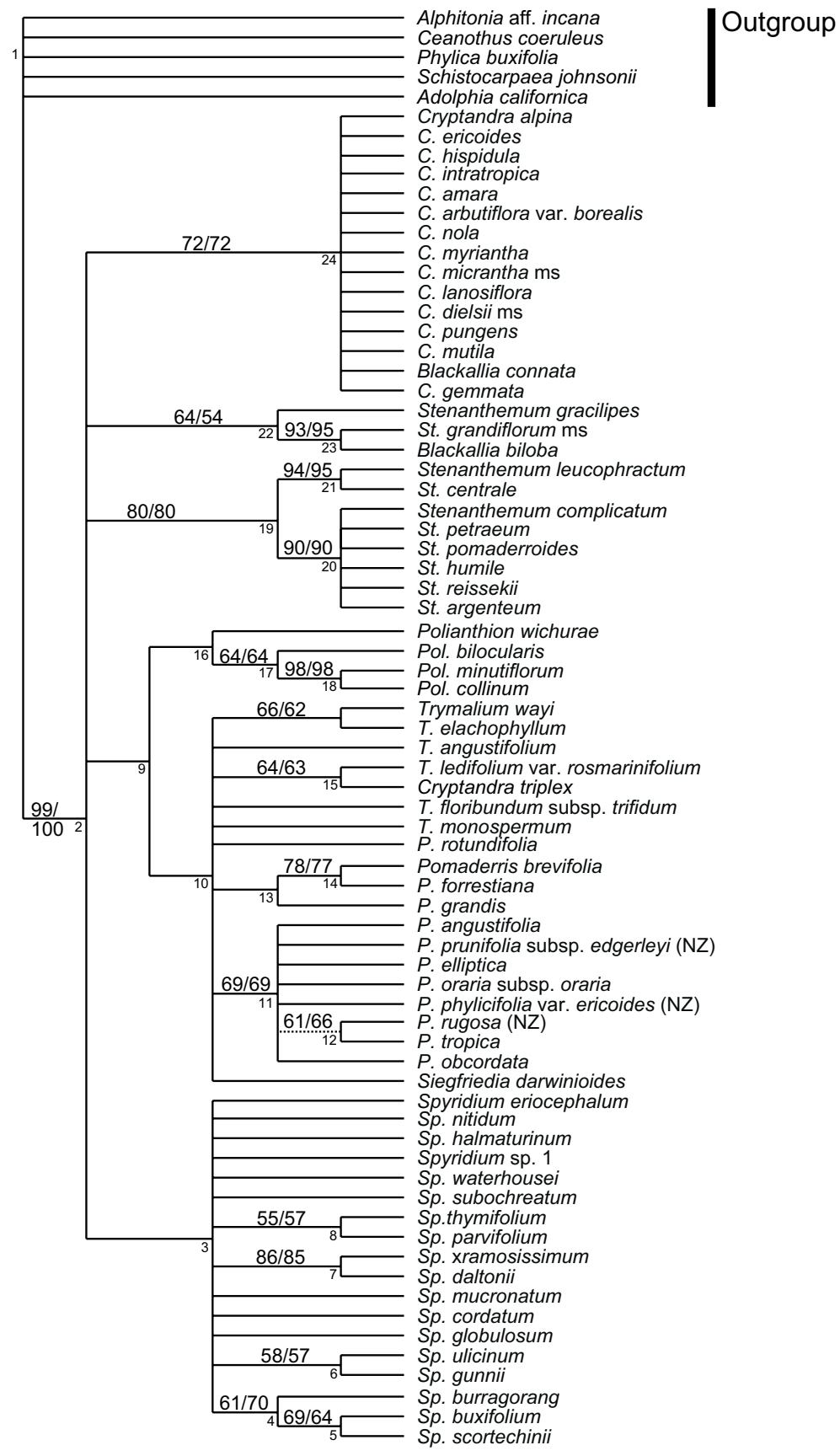

Fig. 3. Strict consensus tree of analysis $\mathrm{C}$ of the $\operatorname{trn} \mathrm{L}-\mathrm{F}$ data-set (10,000 equally parsimonious trees of 259 steps each, $\mathrm{CI}=0.57, \mathrm{RI}=0.81$ ), i.e., parsimony analysis excluding the DNA region containing indel no. 9. Bootstrap/jackknife values are indicated on branches. Node numbers are indicated in smaller type. The branch denoted by a dotted line is only present in bootstrap and jackknife analyses. Species from New Zealand are indicated (NZ). 
Grampians, Victoria, form a strongly supported clade at node 8 (BS: 82\%, JS: 84\%). Spyridium parvifolium and Sp. thymifolium from south-eastern Australia are sister taxa (node 9 with moderate support).

Siegfriedia darwinioides and two clades of Pomaderris form a trichotomy at node 12, which lacks support. Species of Pomaderris from south-eastern Australia and New Zealand group in one strongly supported clade (node 13), while the Western Australian species, $P$. brevifolia, $P$. forrestiana and $P$. grandis, form a second unsupported clade (node 14). Within the clade the relationship of $P$. brevifolia and $P$. forrestiana is strongly supported. Sister to the Siegfriedia-Pomaderris clade is a clade that contains Trymalium species from Western Australia and South Australia (T. wayi). The Trymalium clade does not receive support $>50 \%$ and shows no internal resolution.

If the two species that share indel no. 9 with Trymalium ledifolium, Pomaderris rotundifolia (W.A.) and Cryptandra triplex (N.T.), are included, then these three species form a well supported sub-clade within Trymalium (Fig. 1, node 29; BS: 80\%, JS 81\%). Pomaderris rotundifolia is sister to the other two species.

In analysis C, Siegfriedia, Trymalium and the two Pomaderris clades form a big polytomy (Fig. 3, node 10) in which only a few relationships are resolved, such as the sisterrelationship of $P$. rugosa from New Zealand with $P$. tropica (Qld), and the grouping of T. ledifolium with Cryptandra triplex. In analysis $C, P$. rotundifolia does not group with either of the two Pomaderris clades.

The sister-group to the Pomaderris-Siegfriedia-Trymalium clade is the genus Polianthion, the four species of which group in a moderately supported clade at node 17 (Fig. 2; BS: 66\%, JS: 61\%) that consists of two well supported sub-clades (nodes 18 and 19). Two species from south-western Western Australia, Pol. wichurae and Pol. bilocularis, group in the first sub-clade; Pol. minutifolium from Queensland and Pol. collinum (W.A.) form the second sub-clade. In analysis C, Pol. wichurae is sister to the remaining three species (Fig. 3, node 16); this topology, however does not receive statistical support.

The genus Stenanthemum sensu stricto (according to Rye 1995, 2001 and Thiele 2007) is found at node 21 with high bootstrap and jackknife percentages ( $\geq 89 \%)$. It is divided further into two highly supported groups. One clade at node 23 contains species from southern (St. leucophractum) and central Australia (St. centrale); the second clade (node 22) shows no internal resolution and contains five species from Western Australia and the only representative of the genus in Queensland, St. argenteum.

A group of four species from Western Australia is the sister group to Stenanthemum s. str. (node 24); the relationships between all four species are moderately to highly supported. Stenanthemum gracilipes is sister to the remaining species (BS: 75\%, JS: $71 \%$ ), namely Blackallia connata, B. biloba and St. grandiflorum ms. The two species of Blackallia, however, are not sister taxa, with B. biloba most closely related to St. grandiflorum ms (BS: 66\%, JS: 76\%). Blackallia connata is not part of this clade in analysis C, but is part of the Cryptandra clade (Fig. 3, node 24).

Fourteen species of Cryptandra form a large polytomy in the strict consensus tree (Fig. 2, node 27). This clade receives moderate support with bootstrap and jackknife values $\geq 61 \%$. In analyses A and B, C. gemmata from Arnhem Land (N.T.) is sister to all remaining species, but this relationship is only resolved in the bootstrap and jackknife trees, not in the strict consensus tree (BS: 56\%; JS: 50\%). As stated previously, Blackallia connata is placed in Cryptandra in analysis C. 


\section{Discussion}

\section{Overall characteristics of the trnL-F region}

The analysis of the trn L-F sequence data resulted in a less resolved tree, when compared with the tree generated from ITS data (Kellermann et al. 2005). This is mainly due to fewer informative base and indel characters. The trnL-F data-set contained 110 potentially informative characters, with the ITS region providing 270 informative characters, i.e., more than double the number in a shorter region of DNA. However, the $\mathrm{CI}$ and RI were higher in the trnL-F analyses, indicating less character conflict.

This paucity of informative characters reflects the fact that chloroplast DNA evolves slower than nuclear DNA and that "even non-coding cpDNA regions often fail to provide significant phylogenetic information at low taxonomic levels" (Small et al. 2004, p. 147). The cpDNA region trnL-F provides resolution mainly at the generic level in this analysis. This region neither provides much information about the relationships between genera of Pomaderreae nor resolves the clades well within genera.

\section{Homoplasious indels}

A conspicuous feature of the trnL-F region during alignment and analysis was the presence of two large indels in the $\operatorname{trn} \mathrm{L}$ intron, namely a deletion between bases 380 576 in the alignment (indel no. 9; c. 125 bp) and a deletion between bases 443-487 (indel no. 11, c. 45 bp).

Indel no. 9 groups Trymalium ledifolium, Pomaderris rotundifolia and Cryptandra triplex in analysis A (clade at node 29). This relationship is also supported by a base change from $A$ to $G$ at position 660 in the alignment, which is unique to these species. Results from the analysis of ITS sequences do not support this clade, since they place $C$. triplex into Cryptandra and P. rotundifolia with its congeners into a clade of Pomaderris species from Western Australia. An error during lab-work or cross-contamination of samples can be ruled out, since the DNA extraction of these species and the PCR reactions were done at separate times. In addition, Richardson et al. (2000a) also reported this long indel in their sequence of T. ledifolium; our sequence is identical to that of Richardson and co-workers, with the exception of two deletions of a single nucleotide towards the 3' end of the sequence (base positions 1194 and 1198).

Indel no. 11 occurs in Spyridium buxifolium, Siegfriedia darwinioides, Stenanthemum gracilipes, St. grandiflorum ms, Blackallia connata and B. biloba. However, some of these species are clearly not related, and in the resulting trees of analyses A and B (Fig. 1 \& 2) some are not grouped together: Spyridium buxifolium is related to Sp. burragorang and Sp. scortechinii (node 4), Si. darwinioides is most closely related to Pomaderris (node 12) and the four-taxon clade at node 24 is the sister group to Stenanthemum (node 21). In analysis C, B. connata is part of the Cryptandra clade (Fig. 3, node 24). It is obvious from these results, that indel no. 11 is a homoplasious character and cannot be relied upon for the correct delimitation of relationships. This is corroborated by the placement of these species in the ITS analysis (Kellermann et al. 2005).

The trnL intron, in which both long indels occur, is part of the Group I Intron family and its RNA has a conserved secondary structure (Borsch et al.2003; Cech 1988; Quandt et al. 2004). This complex structure consists of several stem-loop regions and paired 
sequence elements. Borsch et al. (2003, p. 565) have shown that in angiosperms "the P6 and P8 stem-loop regions account for most of the sequence length variation in the $[t r n \mathrm{~L}]$ intron" and can contain highly variable regions. Although a detailed modelling of the secondary structure of the trn L intron has not been attempted here, it is possible to map most of the conserved regions of Group I Introns by simple sequence comparison. Using the secondary structure of Nymphaea odorata Ait. (Borsch et al. 2003, Fig. 2) as a model, it can be deduced that indels no. 9 and no. 11 are indeed located within the P8 stem-loop region. Indel no. 9 nearly encompasses the whole P8 region. It is therefore most likely that these indels are the result of a loss of an arm, stem or loop from the P8 stem-loop region. Homoplasious indels in analyses of non-coding regions of cpDNA have been reported by Morton \& Clegg (1993), Mes et al. (2000) and others, who concluded that homplasious indels can be associated with hairpin structures.

In a phylogeny of land plants, Quandt et al. (2004) excluded the P8 region from the analysis, since it was not alignable across the species in the data-set and was assumed to be not even homologous across all lineages. These authors recommend the exclusion of $\mathrm{P} 8$, and possibly $\mathrm{P} 6$, in studies of higher level phylogenies. This advice was followed in analysis $\mathrm{C}$, where the $\mathrm{P} 8$ region was not included.

The homoplasious indels in Pomaderreae could have been created several times independently, for example in the particularly labile P8 region, which could easily lose a hairpin or stem-loop region. Alternatively, if these homoplasious indels originated only once, they must have been transferred to these species through the introgression of a chloroplast genome containing the indels from one species to another (Rieseberg \& Brunsfeld 1992).

The first possibility seems likely in the case of indel no. 11, which appears independently in at least three lineages: Siegfriedia darwinioides, Spyridium buxifolium, the clade at node 24, and possibly Blackallia connata, if it is part of Cryptandra as suggested by analysis C and the ITS sequence analysis (Kellermann et al. 2005).

The case is equivocal for indel no. 9. The presence of additional supporting characters for clade 29, namely a base change from $A$ to $G$ at position 660 in the alignment, a common base change from $\mathrm{C}$ to A (position 1132) in Trymalium ledifolium and Cryptandra triplex, and the fact that the three species in that clade share an insertion with T. elachophyllum and T. angustifolium (indel no. 8, positions 355-362 in the alignment), suggest a possible single origin of indel no. 9. On the other hand, the sequence of Pomaderris rotundifolia shares a base change from $\mathrm{C}$ to $\mathrm{G}$ (position 836) with all species of Pomaderris and Siegfriedia, as well as a base change from A to $\mathrm{C}$ (position 806) with $P$. forrestiana, which is the sister taxon of $P$. rotundifolia in the ITS sequence analysis (Kellermann et al. 2005). The latter two base changes clearly show a relationship of $P$. rotundifolia with Pomaderris and not with Trymalium and would indicate that indel no. 9 is homoplasious. Flower morphology also supports a relationship of P. rotundifolia with Pomaderris (Walsh \& Coates 1997) and of C. triplex with Cryptandra (Kellermann 2006a).

Since the region in which indels no. 9 and no. 11 occur is part of the highly variable P8 region, which is prone to homoplasious indels, the possibility of more homplasious characters cannot be ruled out, in particular in this region. As such, a phylogenetic analysis $\mathrm{C}$, excluding the region, might be the best representation of the relationships in Pomaderreae, a fact that is corroborated in some degree by slightly higher CI and RI values for analysis $\mathrm{C}$. 


\section{Pomaderreae}

The tribe Pomaderreae is monophyletic and supported with very high bootstrap and jackknife percentages. This confirms the results of the ITS data-set (Kellermann et al. 2005) and of previous analyses, using combinations of $\operatorname{trn} \mathrm{L}-\mathrm{F}$ and $r b c \mathrm{~L}$ sequence data (Fay et al. 2001; Richardson et al. 2000a) and trnL-F/ITS sequences (Richardson et al. 2001; Islam \& Simmons 2006). The sister group to Pomaderreae, however, is unclear from the results of the trnL-F data-set. In previous analyses, either Ceanothus or the tribe Colletieae (Richardson et al. 2000a), or the genera Alphitonia and Granitites (Fay et al. 2001) were the closest relatives to Pomaderreae. Islam \& Simmons (2006) also reported Alphitonia as the weakly to moderately supported sister group to Pomaderreae when analysing combined molecular and morphological data-sets. The results of Kellermann et al. (2005) indicated with weak support that Colletieae (represented by Adolphia) might be the sister taxon to Pomaderreae.

\section{Spyridium}

Species of Spyridium do not form a clade in the strict consensus trees in analyses A and B. However, they group together in $94 \%$ of most parsimonious trees in these analyses (majority rule tree not shown) and in analysis C. Within Spyridium, several species form small clades that are moderately to well supported. A clade of closely related species from New South Wales, Sp. scortechinii and relatives (node 4), and a clade of Tasmanian species (Sp. ulicinum and Sp. gunnii, node 6) were found also in the ITS analysis. This corroborates the unique position of Sp. scortechinii and relatives in the genus; they are the only species of Spyridium in New South Wales with a very long hypanthium tube (Thiele \&West 2004), which was the reason these species were not included in Spyridium for a long time. This feature also occurs in Sp. waterhousei (S.A.), a species that was recently transferred back into Spyridium (Kellermann 2007). Spyridium mucronatum and Sp. cordatum from Western Australia form a well supported clade (node 7), but the position of the third western species, Sp. globulosum, was unresolved. The ITS data-set groups Sp. mucronatum and Sp. globulosum species into one clade (Sp. cordatum was not included in the ITS analysis). The remaining species from south-eastern Australia do not group together, as they do in the ITS results (Kellermann et al. 2005), but form a polytomy. The chloroplast data-set also confirms the close relationship of Sp. daltonii and Sp. xramosissimum (node 8) and corroborates previous findings that these species were misplaced in Trymalium (Kellermann 2006b).

The poor result for Spyridium is caused by both a conflict of characters and lack of informative characters for the group. There is only one synapomorphy for the genus as a whole, a base change from $A$ to $G$ (position 869). In analysis A and B this phylogenetic signal is in conflict with other base changes that occur in the region of indel no. 9. Once this DNA region is excluded (analysis C), species of Spyridium group in one clade. Overall, the results for Spyridium are not in conflict with the ITS analysis

\section{Pomaderris and Siegfriedia}

Pomaderris is divided into two geographically separated clades that form a trichotomy (node 12) with Siegfriedia darwinioides. This highlights the close relationship of Siegfriedia and Pomaderris, which is corroborated by ITS data (Kellermann et al. 2003) and morphology: both genera have a basal valve in each fruitlet of their schizocarpic fruits (Rye 1996b). 
The two Pomaderris clades contain species from Western Australia (node 14) and south-eastern Australia (including New Zealand; node 13), respectively. The clade at node 14 is not supported, only the relationship between $P$. forrestiana and $P$. brevifolia is highly supported. All Western Australian species share a deletion of five bases (indel no. 5, bp 161-164 in the alignment). They have been perceived as distinct from the remaining species of Pomaderris before (N.G. Walsh, pers. comm.), because of their umbellate (or contracted) inflorescences and flowers with a very conspicuous annular disc (Rye 1996b). Most south-eastern Australian species (node 13) have a disc that is inconspicuous or absent. Pomaderris obcordata from mallee scrubland in South Australia and Victoria is part of this clade, and not, as in the ITS analysis, at the base of Pomaderris. It is, however, anomalous in the genus, because of the absence of a clearly defined valve in the fruitlets. A few other species from Pomaderris sect. Apetalae N.G.Walsh, sect. Flabellares N.G.Walsh and sect. Psilogyne N.G.Walsh may not have a clearly defined valve as well (Walsh \& Coates 1997). The south-eastern Australian clade receives high support, but relationships within it are not resolved.

\section{Trymalium}

The sister group to the Siegfriedia-Pomaderris clade is a clade that contains species of Trymalium from Western Australia and South Australia (node 16). This relationship, however, does not receive statistical support $\geq 50 \%$; its synapomorphy is one unique base change at position 878 in the alignment ( $C$ to $G$ ). When Pomaderris rotundifolia and Cryptandra triplex are included (analysis A) they form a clade with Trymalium ledifolium (Fig. 1, node 29), as discussed above. Morphologically, P. rotundifolia displays characters typical for Pomaderris, such as the basal valve in each fruitlet, a deeply divided style, and a densely hairy ovary summit (Rye 1996b). It differs from other species of Pomaderris in its unique, compact, head-like inflorescences and flowers with more strongly hooded petals. Morphologically, C. triplex seems to be very similar to two species of Cryptandra from northern Australia (Kellermann 2006a): $C$. filiformis A.R.Bean (not included in this analysis) and C. intratropica W.Fitzg. The three species share dense indumentum on all parts of the plant. Cryptandra intratropica and C. triplex were included in the ITS analysis and are nested deep within Cryptandra in a clade of northern species (node 52 in Kellermann et al. 2005, Fig. 1). The presence of stipules that are fused around the base of the petiole and a ring of bracts at the base of the flower are important morphological characters (Thiele \& West 2004) that indicate a relationship of $C$. triplex with Cryptandra. The cpDNA characters that place these two species into Trymalium seem to be homoplasious indels and base changes.

\section{Polianthion}

The clade at node 17 unites four species that were labelled as the 'Bilocular Clade' by Kellermann et al. (2005) and have since been described as the new genus Polianthion (Kellermann et al. 2006). It is well supported and consists of two species pairs: Pol. minutiflorum groups with Pol. collinum (node 18; JS/BS: 98\%), and Pol. bilocularis with Pol. wichurae (node 19; JS/BS: $\geq 72 \%$ ). The same relationships were reported by Kellermann et al. (2005), and are corroborated with this cpDNA data-set. The four species share a biloculate ovary and a conspicuous dense indumentum on all surfaces of the plant. The clade is here sister to Pomaderris, Siegfriedia and Trymalium. All 
species in these genera share a 1 bp deletion (indel no. 20, position 1088), but the relationship does not receive bootstrap or jackknife support above $50 \%$. Kellermann et al. (2005) report an association of Polianthion with Cryptandra, Blackallia biloba and Stenanthemum grandiflorum ms, but this too did not receive statistical support.

\section{Stenanthemum}

Three species currently included in Stenanthemum, namely St. gracilipes, St. grandiflorum $\mathrm{ms}$ and St. intropubens Rye ms (the last species not included in this analysis) are in conflict with the definition of the genus (Rye 1995, 2001; Thiele 2007), since they do not share typical morphological characters, such as a disc that is lining the hypanthium tube. Two strongly supported clades containing species of Stenanthemum s. str. (i.e., according to Rye and Thiele) from south-eastern and central Australia (SE-central clade, node 23) and Western Australia and Queensland (WA-Qld clade, node 22) are sister-taxa in the trnL-F analysis (node $21 ; \mathrm{BS} / \mathrm{JS}: \geq 89 \%$ ). This confirms the monophyly of Stenanthemum s. str. These two clades were also found in the ITS results. The atypical species included in the analysis, St. grandiflorum ms and St. gracilipes, appear in the clade at node 24 (see below). This is in contrast to the results of Kellermann et al. (2005), which placed St. gracilipes as sister taxon to the WA-Qld clade with low support (node 35 in Kellermann et al. 2005: BS: 53\%, JS: 57\%).

\section{Species associated with Stenanthemum}

The clade at node 24 that is shown as sister to Stenanthemum, contains four species, which are very different in appearance and habit: St. gracilipes, Blackallia connata, St. grandiflorum $\mathrm{ms}$ and B. biloba.

This clade contradicts the results from the ITS data (Kellermann et al. 2005), in which Blackallia connata is placed into Cryptandra and St. gracilipes into Stenanthemum. However, in analysis C, B. connata falls within a well supported Cryptandra, thus agreeing with the ITS results. The homoplasious nature of some indels in the P8 stemloop region of the $\operatorname{tr} \mathrm{L}$ intron has been discussed above. All characters that unite $B$. connata with these other three species are located within the P8 region, and this grouping might therefore be an artefact of an incorrect phylogenetic signal caused by homoplasious indels (see also Quandt et al. 2004). Once the P8 region is excluded from the analysis, the results also agree with morphology. Blackallia connata has single, sessile flowers that are surrounded by rows of bracts and contain a pubescent disc that surrounds the ovary; the stipules are connate below the attachment point of the petiole. These and other features of the species are typical for Cryptandra (Thiele \& West 2004, Thiele 2007).

The three remaining species in the clade have glabrous discs surrounding the ovary, and a simple cymose inflorescence; stipules are free from one another or connate between petiole and stem. In Stenanthemum gracilipes and Blackallia biloba the flowers have long pedicels. These characters are at odds with the placement of St. gracilipes in the Stenanthemum clade in Kellermann et al. (2005), since putative synapomorphies for Stenanthemum s. str. are a disc that is adnate to the hypanthium tube and sometimes confluent with the filament bases, and dense cymose heads with sessile flowers (Rye 1995, 2001; Thiele 2007). 
Stenanthemum grandiflorum $\mathrm{ms}$ is resolved as the sister taxon to Blackallia biloba in both the trnL-F and ITS analyses. An unnamed species, St. intropubens ms (not included in the analysis), is similar to St. grandiflorum. Although B. biloba shares longpedicellate flowers with St. gracilipes, its flower morphology and habit are distinct from St. gracilipes, St. grandiflorum ms and St. intropubens ms.

Stenanthemum gracilipes has long been seen as a unique species with no apparent close relatives and these results strongly suggest the recognition of a monotypic genus for this species. A new genus containing St. grandiflorum ms and St. intropubens $\mathrm{ms}$ is also supported by our results and was already recommended by Kellermann et al. (2005) as 'New genus A'. The description of these new genera will be published in the near future, in addition to a new circumscription of Blackallia (Kellermann et al., in press).

\section{Cryptandra}

All remaining species of Cryptandra fall into one clade. However, there is no resolution within that clade, with the exception of C. gemmata, which is sister to the remaining species in the jackknife and bootstrap trees, but not in the strict consensus tree. Synapomorphies for the genus Cryptandra were mentioned above and comprise stipules that are connate at the base of the petiole, single flowers, surrounded by row(s) of bracts, a pubescent annular disc around the base of the ovary and schizocarpic fruits that release dehiscent fruitlets (Thiele \& West 2004, Thiele 2007). Cryptandra gemmata is unique in the genus since it is apparently the only species with truly terminal inflorescences (Bean 2004); it is also one of very few species of Cryptandra to occur in the tropical north of Australia (Kellermann 2006a). Some of these tropical species fall into one clade in the analysis of Kellermann et al. (2005, clade at node 52).

\section{Conclusions}

The analysis of DNA sequence data from the chloroplast trnL-F region confirmed most findings of the ITS data-set (Kellermann et al. 2005). However, it was hampered by the lack of informative characters and the presence of apparently homoplasious indel characters and base changes within the P8 region of the trnL intron. As such, the strict consensus tree of the trnL-F analysis was less resolved and had fewer supported clades than in the ITS analysis.

The genera Cryptandra, Stenanthemum and Polianthion were well supported. Species of Trymalium from Western Australia and South Australia formed one clade, but when two taxa with a large homoplasious indel (no. 9), P. rotundifolia and C. triplex, were included in the analysis they appeared in the Trymalium clade. This was also in contrast to the ITS results. Pomaderris was divided into a Western Australian clade and a clade containing south-eastern Australian species; these two clades formed an unresolved trichotomy with the monotypic Siegfriedia. Stenanthemum grandiflorum $\mathrm{ms}$ and Blackallia biloba are confirmed as closely related species. Their sister taxon is $B$. connata, with St. gracilipes next in the phylogenetic sequence, when the P8 region is included in the analysis. When the region is excluded, B. connata changes its position and moves into the Cryptandra clade, a result that is supported both by morphology and ITS sequence data. All species of Spyridium do not group in a clade, but are resolved in a polytomy at the base of Pomaderreae with the clades described above. If the P8 region is excluded, they form a clade, albeit without statistical support. 


\section{Acknowledgments}

The Directors of CANB, MEL and PERTH provided access to specimens and gave permission to remove plant material. We are grateful to the Director of the Australian National Botanic Gardens, Canberra, and the Royal Botanic Gardens Melbourne for permission to collect leaf material from their living collections. Collection permits and free access to FloraBase were provided by the Western Australian Department of Environment and Conservation (formerly CALM). Further plant material was obtained from Dave Albrecht (NT), Barbara Archer (Esperance), Alex Buchanan (HO), D.V. Matthews \& T.L. Collins (Alice Springs), J. Read (Grampians National Park) and Neville Walsh (MEL). The following people helped and assisted during field work in W.A.: Don Bellair (Kalbarri), the late Brenda Hammersley (Denmark), Mike Hislop (PERTH), Fred Hort (Perth), Sue Patrick (PERTH), Irene \& Owen Shepherd (Northhampton), Don \& Joy Williams (Badgingarra). J.K. acknowledges the receipt of a Melbourne Research Scholarship, the Sophie Ducker Postgraduate Scholarship and the Dawson Bursary from the University of Melbourne. His travel expenses to attend the 2006 ASBS conference in Cairns were provided by the Royal Botanic Gardens Melbourne. This study was in part supported by a Melbourne University Research Development Grant to P.Y. Ladiges (School of Botany, The University of Melbourne).

\section{References}

Aagesen L, Medan D, Kellermann J \& Hilger H H (2005) Phylogeny of the tribe Colletieae (Rhamnaceae) - a sensitivity analysis of the plastid region trnL-trnF. Plant Systematics and Evolution 250: 197-214.

Bean AR (2004) New species of Cryptandra Sm. and Stenanthemum Reissek (Rhamnaceae) from northern Australia. Austrobaileya 6: 917-940.

Bolmgren K \& Oxelman B (2004) Generic limits in Rhamnus L. s.l. (Rhamnaceae) inferred from nuclear and chloroplast DNA sequence phylogenies. Taxon 53: 383-390.

Borsch T, Hilu KW, Quandt D, Wilde V, Neinhuis C \& Barthlott W (2003) Noncoding plastid

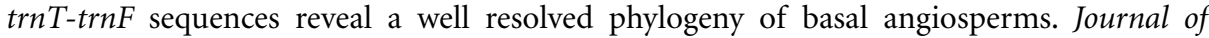
Evolutionary Biology 16: 558-576.

Cech TR (1988) Conserved sequences and structures of group I introns: building an active site for RNA catalysis - a review. Gene 73: 259-271.

Crisp M \& Cook L (2003) Molecular evidence for definition of genera in the Oxylobium group (Fabaceae: Mirbelieae). Systematic Botany 28: 705-713.

Farris JS, Albert VA, Källersjö M, Lipscomb D \& Kluge AG (1996) Parsimony jackknifing outperforms neighbourhood-joining. Cladistics 12: 99-124.

Fay MF, Lledó MD, Richardson JE, Rye BL \& Hopper SD (2001) Molecular data confirm the affinities of the south-west Australian endemic Granitites with Alphitonia (Rhamnaceae). Kew Bulletin 56: 669-675.

Felsenstein J (1985) Confidence limits on phylogenies: an approach using bootstrap. Evolution 39: 783-791.

Gielly L \& Taberlet P (1994) The use of chloroplast DNA to resolve plant phylogenies: Noncoding versus $r b c \mathrm{~L}$ sequences. Molecular Biology and Evolution 11: 769-777.

Ham RCHJ van, Hart HT, Mes THM \& Sandbrink JM (1994) Molecular evolution of noncoding regions of the chloroplast genome in the Crassulaceae and related species. Current Genetics 25: 558-566.

Holmgren PK, Holmgren NH \& Barnett LC (eds) (1990) Index Herbariorum. (New York Botanic Garden Press: New York) 
Islam MB \& Simmons MP (2006) A thorny dilemma: testing alternative intrageneric classifications within Ziziphus (Rhamnaceae). Systematic Botany 31: 826-842.

Kellermann J (2006a) Cryptandra triplex K.R.Thiele ex Kellermann, a new species of Rhamnaceae (Pomaderreae) from Arnhem Land, Northern Territory. Austrobaileya 7: 299-303.

Kellermann J (2006b) New combinations for two species of Spyridium (Rhamnaceae: Pomaderreae) from the Grampians, Victoria. Muelleria 22: 97-104.

Kellermann J (2006c) A range extension for Cryptandra pogonoloba (Rhamnaceae: Pomaderreae) and recognition of a new subspecies. Muelleria 24: 45-50.

Kellermann J (2007) Re-instatement of the name Spyridium waterhousei from Kangaroo Island, South Australia, with a short history of the tribe Pomaderreae (Rhamnaceae). Journal of the Adelaide Botanic Gardens 21: 55-62.

Kellermann J, Rye BL \& Thiele KR (2006) Polianthion, a new genus of Rhamnaceae (Pomaderreae) from Western Australia and Queensland. Australian Systematic Botany 19: 169-181.

Kellermann J, Rye BL \& Thiele KR (in press) Blackallia, Serichonus and Papistylus: three closely related genera of Rhamnaceae (Pomaderreae) from south-western Australia. Nuytsia.

Kellermann J \& Udovicic F (2007) A revision of the Cryptandra propinqua complex (Rhamnaceae: Pomaderreae). Proceedings of the Linnean Society of New South Wales 128: 81-98.

Kellermann J, Udovicic F \& Ladiges PY (2005) Phylogenetic analysis and generic limits of the tribe Pomaderreae (Rhamnaceae) using internal transcribed spacer DNA sequences. Taxon 53: 619-631.

Maddison WP, Donoghue MJ \& Maddison DR (1984) Outgroup analysis and parsimony. Systematic Zoology 33: 83-103.

Medan D \& Schirarend C (2004) Rhamnaceae. Pp. 320-338 in Kubitzki K (ed.) The Families and Genera of Vascular Plants, vol. 6. (Springer: Berlin \& Heidelberg)

Mes THM, Kuperus P, Kirschner J, Stepanek J, Oosterveld P, Storchova H \& den Nis JCM (2000) Hairpins involving both inverted and direct repeats are associated with homoplasious indels in non-coding chloroplast DNA of Taraxacum (Lactuceae: Asterceae). Genome 43: 634-641.

Morton BR \& Clegg MT (1993) A chloroplast DNA mutational hotspot and gene conversion in a non-coding region near $r b c \mathrm{~L}$ in the grass family (Poaceae). Current Genetics 24: 357-365.

Murphy DJ, Udovicic F \& Ladiges PY (2000) Phylogenetic analysis of Australian Acacia (Leguminosae: Mimosoideae) by using sequence variation of an intron and two intergenic spacers of chloroplast DNA. Australian Systematic Botany 13: 745-754.

Plunkett GM, Wen J \& Lowry II PP (2004) Infrafamilial classifications and characters in Araliaceae: insights from the phylogenetic analysis of nuclear (ITS) and plastid (trnL-trnF) sequence data. Plant Systematics and Evolution 245: 1-39.

Quandt D, Müller K, Stech M, Frahm J-P, Frey W, Hilu KW \& Borsch T (2004) Molecular evolution of the chloroplast trnL-F region in land plants. Pp. 13-37 in Goffinet B, Hollowell V \& Magill R (eds), Molecular systematics of bryophytes. (Missouri Botanical Gardens Press: St. Louis)

Richardson JE, Fay MF, Cronk QCB, Bowman D \& Chase MW (2000a) A phylogenetic analysis of Rhamnaceae using $r b c \mathrm{~L}$ and $\operatorname{trn} \mathrm{L}-\mathrm{F}$ plastid sequences. American Journal of Botany 87: 1309-1324.

Richardson JE, Fay MF, Cronk QCB \& Chase MW (2000b) A revision of the tribal classification of Rhamnaceae. Kew Bulletin 55: 311-340.

Richardson JE, Weitz FM, Fay MF, Cronk QCB, Linder HP, Reeves G \& Chase MW (2001) Phylogenetic analysis of Phylica L. (Rhamnaceae) with an emphasis on island species: evidence from plastid trnL-F and nuclear internal transcribed spacer (ribosomal) DNA sequences. Taxon 50: 405-427.

Rieseberg LH \& Brunsfeld SJ (1992) Molecular evidence of plant introgression. Pp. 151-176 in Soltis DE, Soltis PS \& Doyle JJ (eds), Molecular systematics of plants. (Chapman \& Hall: London)

Rossetto M, Jackes BR, Scott KD \& Henry RJ (2001) Intergeneric relationships in the Australian Vitaceae: new evidence from cpDNA analysis. Genetic Resources and Crop Evolution 48: 307314. 
Rye BL (1995) New and priority taxa in the genera Cryptandra and Stenanthemum (Rhamnaceae) of Western Australia. Nuytsia 10: 255-305.

Rye BL (1996a) Granitites, a new genus of Rhamnaceae from the south-west of Western Australia. Nuytsia 10: 451-457.

Rye BL (1996b) A synopsis of the genera Pomaderris, Siegfriedia, Spyridium and Trymalium (Rhamnaceae) in Western Australia. Nuytsia 11: 109-131.

Rye BL (2001) A taxonomic update of Stenanthemum (Rhamnaceae: Pomaderreae) in Western Australia. Nuytsia 13: 495-507.

Simmons MP \& Ochoterena H (2000) Gaps as characters in sequence-based phylogenetic analyses. Systematic Biology 49: 369-381.

Simon D, Fewer D, Friedl T \& Bhattacharya D (2004) Phylogeny and self-splicing ability of the plastid tRNA-Leu group I intron. Journal of Molecular Evolution 57: 710-720.

Small RL, Cronn RC \& Wendel JF (2004) Use of nuclear genes for phylogeny reconstruction in plants. Australian Systematic Botany 17: 145-170.

Swofford D (2002) PAUP*: Phylogenetic Analysis Using Parsimony ( ${ }^{*}$ and other methods). Version 4. (Sinauer Associates: Sunderland, Massachusetts)

Sytsma KJ, Morawetz J, Pires JC, Nepokroeff M, Conti E, Zjhra M, Hall JC \& Chase MW (2002) Urticalean rosids: circumscription, rosid ancestry, and phylogenetics base on $r b c \mathrm{~L}, \operatorname{trn} \mathrm{L}-\mathrm{F}$, and $n d h \mathrm{~F}$ sequences. American Journal of Botany 89: 1531-1546.

Taberlet P, Gielly L, Pautou G \& Bouvet J (1991) Universal primers for amplification of three non-coding regions of chloroplast DNA. Plant Molecular Biology 17: 1105-1109.

Thiele KR (2007) Two new species of Australian Stenanthemum (Rhamnaceae: Pomaderreae). Journal of the Adelaide Botanic Gardens 21: 67-74.

Thiele KR \& West JG (2004) Spyridium burragorang (Rhamnaceae), a new species from New South Wales, with new combinations for Spyridium buxifolium and Spyridium scortechinii. Telopea 10: 823-829.

Thulin M, Bremer B, Richardson JE, Niklasson J, Fay MF \& Chase MW (1998) Family relationships of the enigmatic rosid genera Barbeya and Dirachma from the Horn of Africa region. Plant Systematics and Evolution 213: 103-119.

Udovicic F \& Murphy DJ (2002) Successful DNA amplification from Acacia (Leguminosae) and other refractory Australian plants and fungi using a nested/semi-nested PCR protocol. Muelleria 16: 47-53.

Walsh NG (1988) Two new species of Pomaderris Labill. (Rhamnaceae) from south-eastern New South Wales. Muelleria 6: 429-435.

Walsh NG (1990) The Pomaderris oraria F.Muell. complex in Australia. Muelleria 7: 267-287.

Walsh NG \& Coates F (1997) New taxa, new combinations and an infrageneric classification in Pomaderris (Rhamnaceae). Muelleria 10: 27-56.

Yuan Y-M, Wohlhauser S, Möller M, Chassot P, Mansion G, Grant J, Küpfer P \& Klackenberg J (2003) Monophyly and relationships of the tribe Exaceae (Gentianaceae) inferred form nuclear ribosomal and chloroplast DNA sequences. Molecular Phylogenetics and Evolution 28: $500-517$.

Manuscript received 11 January 2007, accepted 27 August 2007 


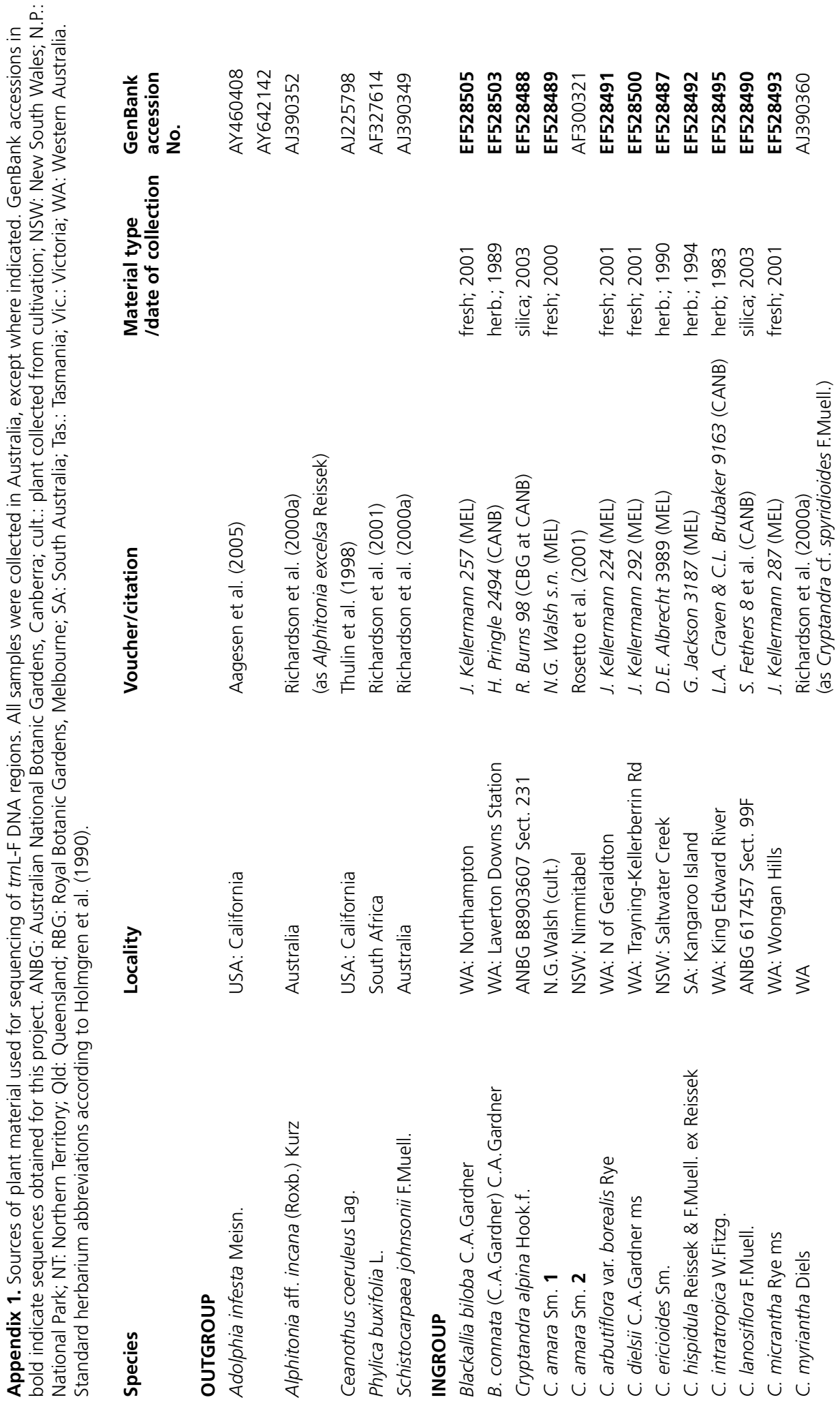




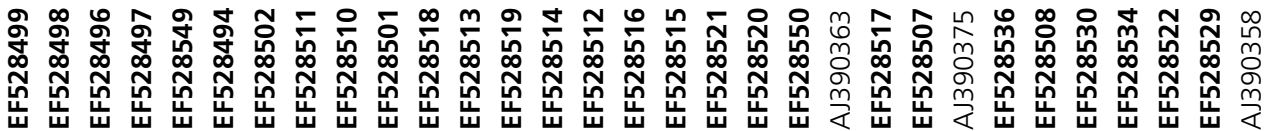

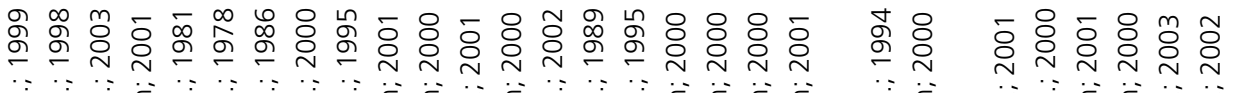

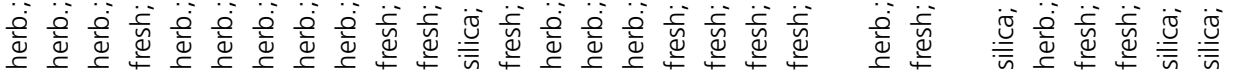
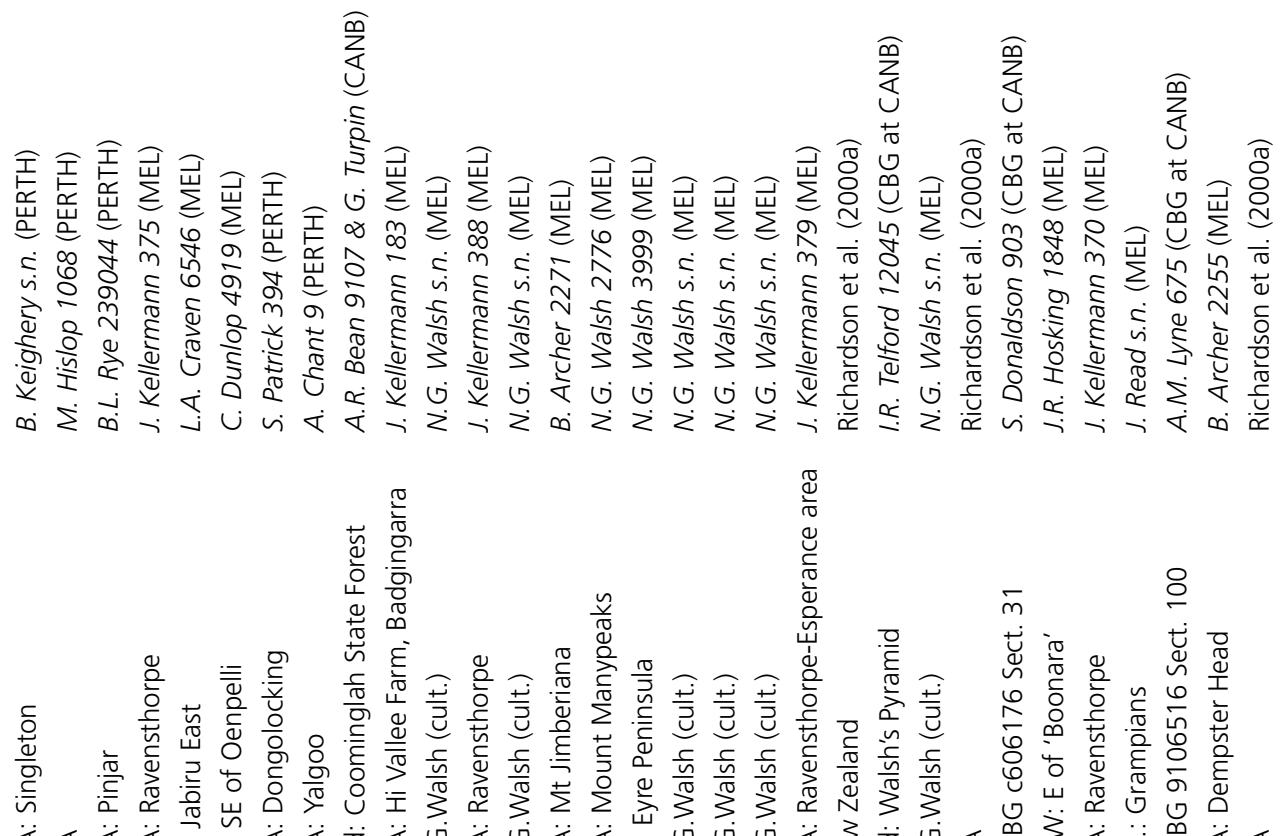

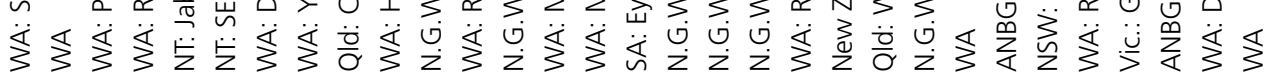

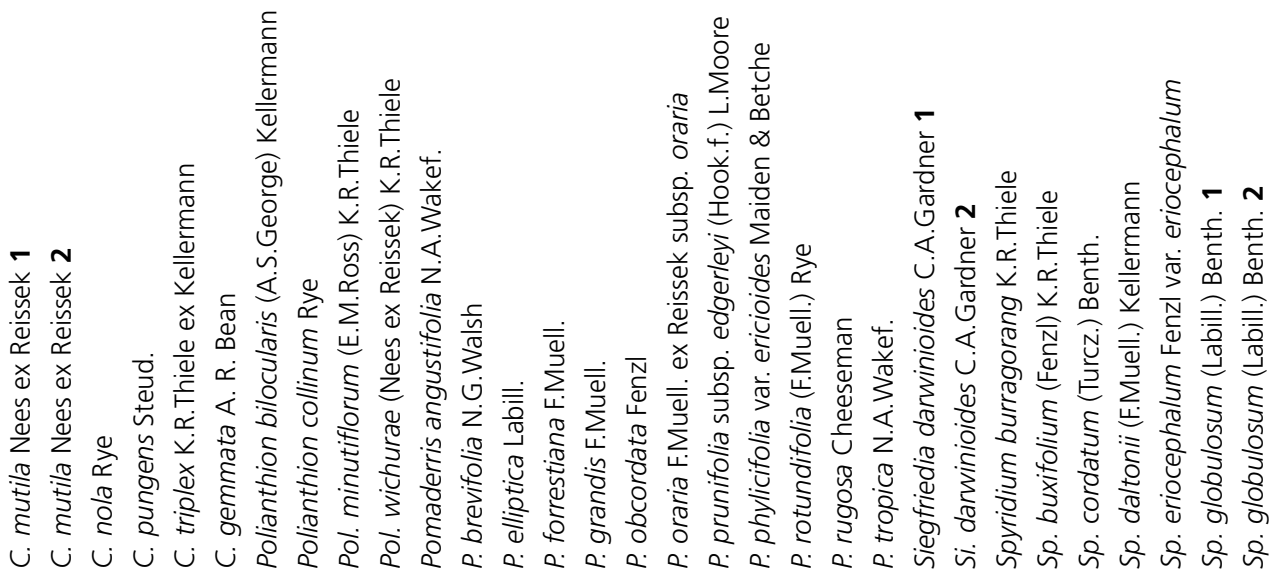



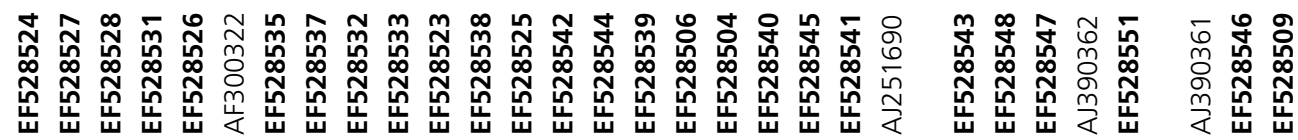

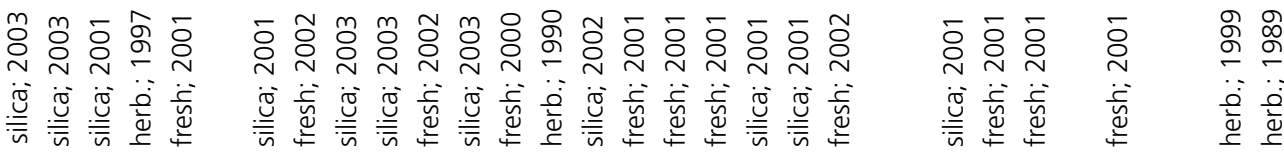

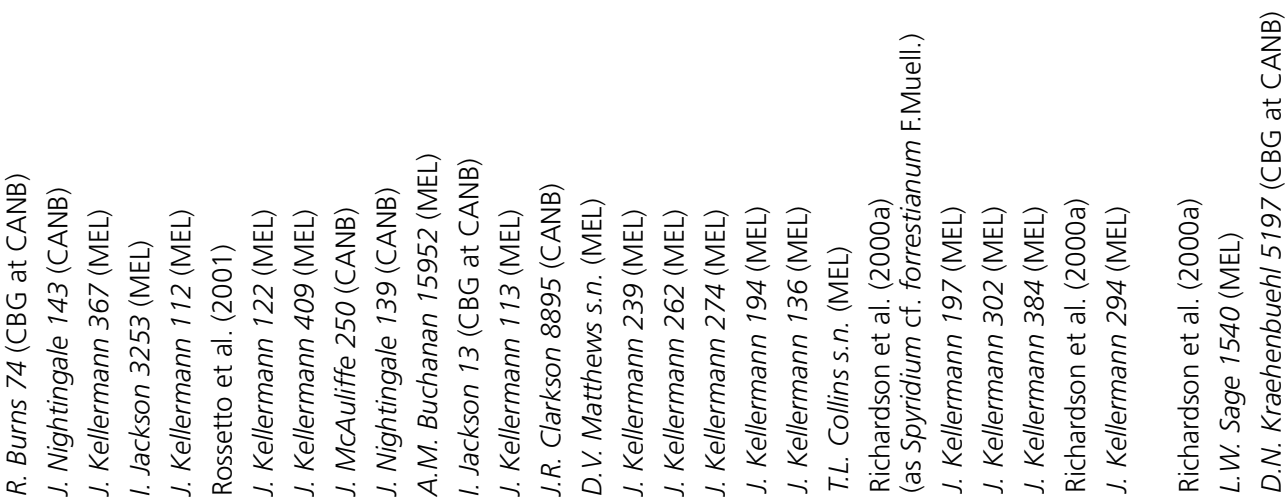

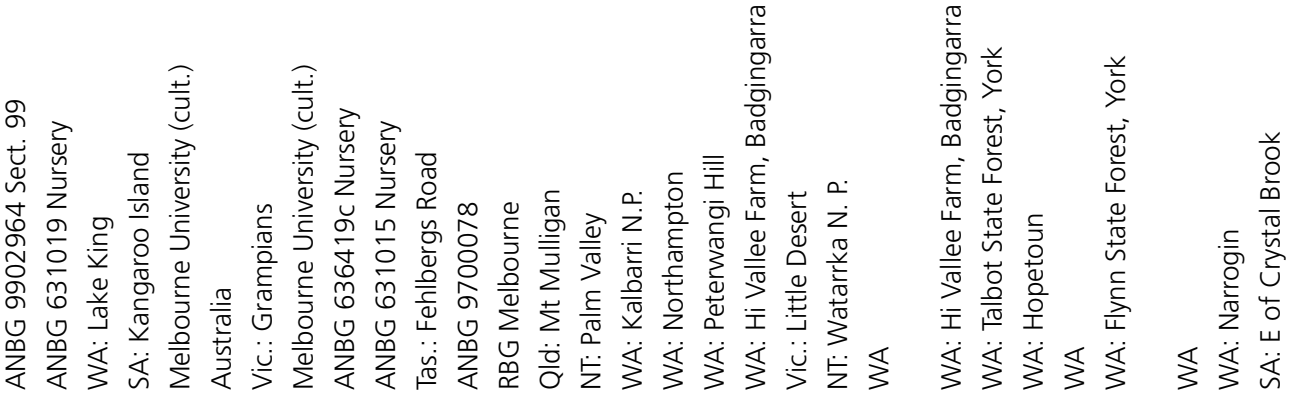

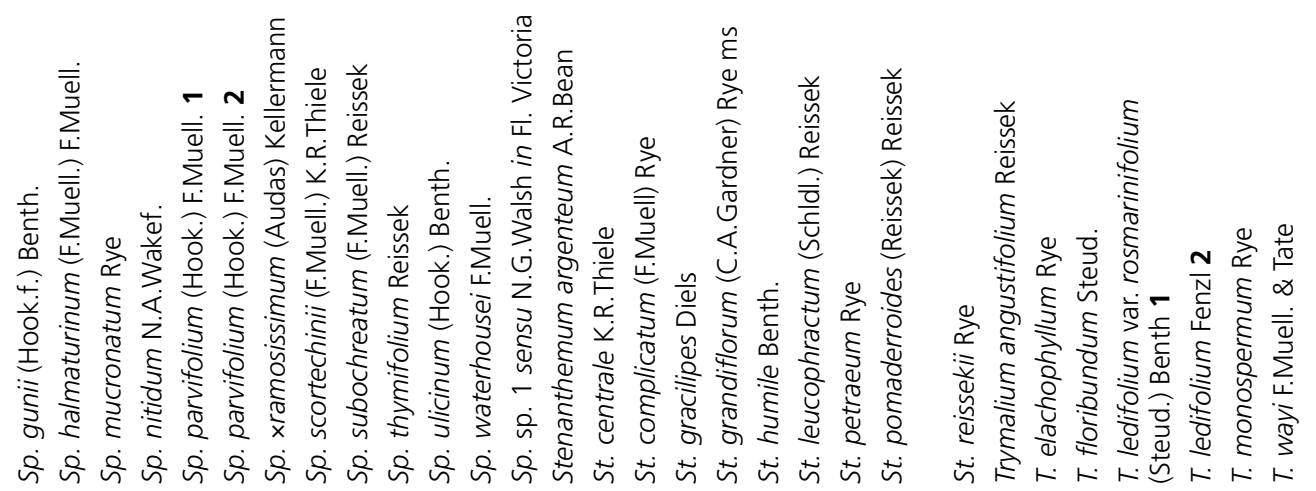

